\title{
Arizona's tobacco control initiative illustrates the need for continuing oversight by tobacco control advocates
}

\author{
Stella Aguinaga Bialous, Stanton A Glantz
}

\begin{abstract}
Background-In 1994, Arizona voters approved Proposition 200 which increased the tobacco tax and earmarked $23 \%$ of the new revenues for tobacco education programmes.

Objective-To describe the campaign to pass Proposition 200, the legislative debate that followed the passage of the initiative, and the development and implementation of the tobacco control programme.

Design-This is a case study. Data were collected through semi-structured interviews with key players in the initiative campaign and in the tobacco education programme, and written records (campaign material, newspapers, memoranda, public records).

Results-Despite opposition from the tobacco industry, Arizonans approved an increase in the tobacco tax. At the legislature, health advocates in Arizona successfully fought the tobacco industry attempts to divert the health education funds and pass preemptive legislation. The executive branch limited the scope of the programme to adolescents and pregnant women. It also prevented the programme from attacking the tobacco industry or focusing on secondhand smoke. Health advocates did not put enough pressure at the executive branch to force it to develop a comprehensive tobacco education programme.
\end{abstract}

Conclusions-It is not enough for health advocates to campaign for an increase in tobacco tax and to protect the funds at the legislature. Tobacco control advocates must closely monitor the development and implementation of tax-funded tobacco education programmes at the administrative level and be willing to press the executive to implement effective programmes. (Tobacco Control 1999;8:141-151)

Keywords: tobacco tax; health education; advocacy

\section{Introduction}

In November 1994, Arizona became the third state to pass an initiative to raise tobacco taxes and use a percentage of the new revenues to fund a state wide tobacco control programme (Proposition 200). Like California in 1988 (Proposition 99) ${ }^{12}$ and Massachusetts in 1991 (Question 1), ${ }^{3-5}$ Arizona was entering a new phase in the public health effort to decrease tobacco-related morbidity and mortality. Health advocates in California and Massachusetts have failed in several instances to protect their tobacco control programme from attacks by the tobacco industry. ${ }^{13-9}$ In both these states, the tobacco control programmes mandated by the voter were weakened by diversion of funds by the legislature and by the weakening of the messages of the programmes by the executive branch. Their failure to protect the health education programme as mandated by voters was largely due to compromises made in the early stages of developing legislation and structuring the programmes. Health advocates in Arizona encountered the same problems. Although the advocates in Arizona were able to prevent diversion of tobacco education funds to other programmes, they did not effectively press the executive branch to implement a maximally effective tobacco control programme.

After passage of Proposition 200, there was an increase in the tobacco industry political activity in Arizona. Arizona's campaign finance and lobbying disclosure laws are too weak to allow a clear assessment of the relationship between tobacco industry money and legislative behaviour, ${ }^{10-12}$ but the influence of tobacco lobbyists in the Arizona legislature has been well documented by the media. ${ }^{13-17}$ In addition to lobbying activity, the tobacco industry's National Smokers' Alliance has been very active in (unsuccessful) attempts to prevent local clean indoor air ordinances from passing and going into force. ${ }^{10}{ }^{18-22}$

\section{Methods}

This is a case study of the passage of Arizona's Proposition 200, the tobacco tax initiative, of the legislative debate that followed, and how the state health department developed its tobacco control programme. Data were gathered from written records, newspaper clippings, and semi-structured interviews with key players in the Coalition for Tobacco Free Arizona (CTFA), Arizona Department of Health Services, legislators, and other tobacco control advocates in Arizona. Key players in the opposition campaign did not return phone calls inviting them to participate in the study. Participants were invited to comment on drafts of an earlier report that presented some of our results. ${ }^{10}$ Data presented here were collected between 1995 and 1997. There were changes in the programme since the end of formal data collection. These changes are noted when appropriate. 
Proposition 200: the ballot campaign

On 8 November 1994, Arizona voters passed Proposition 200 by a margin of $50.7 \%$ to $49.3 \%,{ }^{23}$ which increased the cigarette excise tax by US $\$ 0.40$, with proportional increases in the tax on other tobacco products, and earmarked the new revenues in four accounts. ${ }^{24}$

- Health education account $-23 \%$ for tobacco prevention/education programmes

- Health research account-5\% for tobaccorelated diseases and prevention research

- Medically needy account- $70 \%$ to provide medical care for the poor

- Adjustment account- $2 \%$ to offset future loss of tobacco tax revenues by the Arizona Department of Corrections.

The idea for Proposition 200 originated with John Rivers, chief executive officer of Arizona Hospital and Healthcare Association (AzHA, then called Arizona Hospital Association) who, in November 1992, began examining ways of raising funds for Arizona's Medicaid programme, the Arizona health care cost containment system (AHCCCS), which pays for medical care for the uninsured. Previous attempts to work with the legislature to raise tobacco taxes had failed. Arizona is a fiscally conservative state, and increasing funds for health and welfare items seldom appears on its formal agenda. ${ }^{25}$ Therefore, the initiative was the only viable way of achieving AzHA's goal of increasing funds for AHCCCS. Polling data showed that $75 \%$ of the public supported a tobacco tax increase, provided that the money raised was specifically directed to health care for the poor. ${ }^{26}$ In addition to raising money for AHCCCS, Rivers believed the tobacco tax would help decrease tobacco use, a public health measure congruent with AzHA's goals.

AzHA studied the experience in states that had passed (California and Massachusetts) ${ }^{1-5}$ or attempted to pass (Montana, Arkansas, and Colorado) ${ }^{27-29}$ tobacco tax initiatives. ${ }^{30}$ They conducted opinion polls to establish a publicly palatable amount of tax and tested the general public's support for a tobacco tax increase. From this information, it was clear that a ballot initiative was feasible, and that a tax increase of $\$ 0.40$ per cigarette pack (with proportional increases in other tobacco products) was the most appropriate course of action. ${ }^{30}$ The polls indicated public support for a tax high enough to have made Arizona the state with the highest cigarette tax in the country. ${ }^{25}$ To be cautious, initiative proponents set the tax lower to prevent opponents from using the fact that Arizona would have the highest cigarette tax in the nation against them.

Rivers contacted Jack Nicholl, a Californiabased political consultant who had managed the campaign to pass Proposition 99 in California in $1988,{ }^{1}$ a tobacco-tax initiative similar to the one Rivers had in mind and also contacted the voluntary health agencies-the American Cancer Society (ACS), the American Heart Association (AHA), and the American Lung Association (ALA) - to seek their support. These agencies embraced the opportunity of joining forces with the hospital association. AzHA gave the voluntary bodies
Table 1 Contributions to support Arizona's Proposition 200

\begin{tabular}{ll}
\hline Arizona for a Healthy Future contributor & Amount (US\$) \\
\hline Hospitals and healthcare groups & 698195 \\
$\quad$ Arizona Hospital Association & 932206 \\
Hospitals and healthcare centres/groups & 1630401 \\
Subtotal & \\
Voluntary/non-profit health groups & 86046 \\
$\quad$ American Cancer Society, AZ division & 62263 \\
American Heart Association & 3675 \\
American Lung Association & 4343 \\
Arizonans Concerned About Smoking & 11034 \\
Navajo Nation Health Foundation & 2000 \\
Mayo Foundation for Medical & 169361 \\
$\quad$ Education & \\
Subtotal & 75229 \\
Other businesses and individuals & 1874991 \\
Subtotal & \\
Total &
\end{tabular}

Source: Arizona secretary of state campaign finance report, Source: Arizona secretary of state campaign finance report, Healthy Future, 31 January 1995.

Healthy Future, 31 January 1995.
Note: The post-general election report describing additional contributions of $\$ 47057$ was not found at the secretary of state office.

the funds and the political capital necessary to pursue the idea of a higher tobacco tax, despite the lack of support that some individual hospitals demonstrated for the initiative. ${ }^{31}$ At the same time, AzHA needed the legitimacy and public trust that the voluntary health agencies provided. As discredited as the tobacco industry is, the hospital and healthcare industry did not fare much better in the public's eyes. ${ }^{32}$

Initiative proponents wanted to avoid the portrayal of the campaign as wealthy doctors and hospitals fighting with the wealthy tobacco industry over the public's money. The tobacco industry had used this message in other states that had considered tobacco tax initiatives, and proponents expected the same in Arizona. ${ }^{14527}$ Thus, AzHA kept a low profile with the public, and the voluntary agencies - mainly ACS - assumed the "spokesperson" role: addressing the media, participating in events, and being the most visible supporters of the initiative campaign. The hospitals, however, provided $86 \%$ of the financial support for the initiative (table 1).

The proponents of the initiative created Arizona for a Healthy Future (AHF), a coalition of health, business, and education groups, to pass Proposition 200. The three voluntary agencies (ACS, AHA, and ALA) plus AzHA formed the executive committee of AHF. Advocates from the smaller, grassroots tobacco control organisations Arizonans Concerned About Smoking and Non-Smokers, Inc also joined the coalition and mobilised their extensive grassroots base in support of the initiative.

The petition drive was launched in February 1994, at which time former United States Senator Barry Goldwater (Republican) joined the coalition and became campaign chairman. Goldwater, an icon in Arizona politics with a high profile, was key to the strategies for securing media attention and attracting supporters to the initiative. ${ }^{32}{ }^{33}$ The campaign focused on protecting children and saving lives, not on the taxation issue. $^{30}{ }^{32-38}$ On 1 July 1994, AHF filed 205000 signatures (105 541 valid signatures were required) with the secretary of state to qualify the Tobacco Tax and Health Care Act 
for the ballot on 8 November 1994. By collecting twice as many signatures as required, proponents avoided a challenge of the validity of signatures by the tobacco industry. (The industry kept similar initiatives off the ballot in Colorado in 1990 and in Arkansas and Nebraska in 1992, by challenging the validity of the signatures. ${ }^{29}$ ) The campaign received public support from former Surgeon General C Everett Koop, who came to Arizona to participate in fundraising events and press conferences. Koop's involvement received wide media attention, in favour of and against the initiative. ${ }^{39-42}$

Even before it qualified, Governor Fife Symington (R), Senate President John Greene ( $R$, Phoenix), and several other prominent lawmakers opposed the initiative. ${ }^{43}$ Their opposition was nominally based on two premises: first, they thought that fiscal issues, such as a new tax, should be decided by the legislature, not the public at large. They claimed that hospitals would "pocket the money", circumventing the appropriation process, using California's Proposition 99, as an example. ${ }^{44}$ (In California, with the support of the tobacco industry and the California Medical Association, ${ }^{14-48}$ the legislature diverted $\$ 273814000$ from the health education account and $\$ 71345000$ from the research account to pay for medical services not related to tobacco control. ${ }^{6}$ ) Second, Symington, Greene, and others said they did not approve of authority for public policymaking being overridden by the initiative process.

At an April 1994 meeting in the governor's office with the voluntary health agencies and the hospital association, Governor Symington and Senate President Greene expressed their opposition to the initiative and asked the health groups to stop the signature campaign. They threatened retaliation such as removal of non-profit status of the organisations supporting the initiative, blocking any future legislation that proponents of this initiative supported, and legislative measures to punish the hospitals, such as regulating hospital rates and withholding payments. ${ }^{45} 40$ Arizona for a Healthy Future denounced the pressure tactics to the press and the threats received wide media attention.

Following its established pattern, the industry used front-groups, "Enough is Enough" and "No More Taxes", 99.96\% financed by Philip Morris and the Tobacco Institute, respectively (table 2 ) to campaign against the initiative. ${ }^{14527}$ As expected, the tobacco industry portrayed the initiative as an attempt by its proponents to divert large amounts of taxpayer money to their own benefit rather than to the public interest. No More Taxes used the diversion of health education funds into medical services by the California legislature as an example of how the tobacco tax funds were going to benefit only the hospitals. ${ }^{51-53}$ This argument seemed particularly hypocritical to public health advocates, as the tobacco industry was one the major sources of political pressure supporting diversion of funds away
Table 2 Contributions to oppose Arizona's Proposition 200

\begin{tabular}{ll}
\hline Contributor & Amount (US\$) \\
\hline Enough is Enough & \\
Philip Morris USA & 413532 \\
Retail Grocers Association & 450 \\
Other & 400 \\
Subtotal & 414382 \\
No More Taxes & 5402716 \\
The Tobacco Institute & 50000 \\
Arizona Executive Committee & 426 \\
Enough is Enough & 1120 \\
Other & 5454262 \\
Subtotal & 5868645 \\
Total &
\end{tabular}

${ }^{\star}$ A group created by the tobacco industry to support political campaigns.

Source: Arizona secretary of state campaign finance report, statement of contributors and expenditures for committees: Enough is Enough, October 1994, and No More Taxes, December, 1994.

from anti-tobacco education into medical services. ${ }^{69}$ These accusations increased opposition from the media to the initiative. ${ }^{3954}$ Another part of the industry's campaign was to claim that California's tobacco control programme was misusing public funds, similar to a campaign that the tobacco industry was waging in California. ${ }^{5155}$

Despite being outspent three to one, Proposition 200 won by $50.7 \%$ to $49.3 \%$ of the popular vote on 8 November 1994 .

\section{After the vote}

Passage of the initiative provided for the collection of the tobacco tax and established the accounts to which the funds should be allocated. The selection of and funding for specific programmes had to be determined by the legislature.

Immediately after Proposition 200 passed, representatives from the voluntary health agencies and AzHA met with legislators to discuss the legislature's role in the implementation of Proposition 200. They recognised that passing the initiative was the first step in developing and implementing a comprehensive tobacco control programme for Arizona. The executive committee of Arizona for a Healthy Future stayed together, an important step to protect the initiative against legislative attempts to divert the funds to uses other than those specified in the language of the Proposition. ${ }^{32}$ Experience from California ${ }^{1}$ and Massachusetts $^{49}$ demonstrated that after the passage of the initiative it is important for its supporters to present a unified front to the legislature, to ensure the allocation of funds as approved by the voters.

The voluntary health agencies recognised the need for professional and competent assistance in dealing with the legislature $e^{32567}$ and hired one of the top 10 lobbyists in Arizona, Kevin DeMenna. ${ }^{15}$ AzHA lobbyist Laurie Lange and DeMenna met frequently with Representative Sue Gerard (R, Phoenix), chair of the house health committee, to discuss the appropriation of the tobacco tax funds into the Medically Needy and the Health Education accounts. Some health advocates did not expect her support because she was a smoker and had a personal friendship with Philip 
Morris lobbyist Rip Wilson. ${ }^{58}$ Representative Gerard has proven to be one of the strongest protectors of the tobacco tax funds.

The tax went into effect immediately upon passage of the initiative, and it raised $\$ 55.5$ million in the first seven months (November 1994 to June 1995, part of fiscal year (FY) 1995 ) and over $\$ 120$ million a year beginning in FY 1996 (July 1995 to June 1996). The legislature would have to consider the appropriation of funds collected in the current fiscal year, plus the funds that had accumulated while an appropriation bill was not approved, effectively increasing the amount of funds available to each of the four accounts established by Proposition 200. At the same time, tobacco lobbying activity at the state legislature increased, with the number of paid tobacco industry lobbyists rising from approximately four to $18 . .^{57}$

\section{Legislative session 1995}

At the opening of the legislative session in January 1995 , at least 12 bills addressing the allocation of the tobacco funds were introduced, most trying to place the money in the general fund in direct violation of Proposition 200. In general the media opposed the legislature's attempt to divert money from Proposition 200 into the general fund. ${ }^{59}{ }^{60}$ In contrast to California, ${ }^{16-861}$ and Massachusetts, ${ }^{39}$ Arizona health advocates insisted that no funds allocated by the voters to tobacco education programmes be diverted to medical services and that the initiative was to be implemented as the voters passed it. This position was supported by the united front that proponents of Proposition 200 maintained throughout the legislative debate. A poll conducted for AzHA by Arizona Opinion and Political Research in March 1995 confirmed that $64 \%$ of respondents agreed with the outcome of the election that increased the tobacco tax, and that $90 \%$ wanted the legislators to honour the intent of Proposition 200. ${ }^{62}$

At the same time that health advocates were working to secure appropriation of Proposition 200 funds, they also had to stop a series of protobacco bills that would have preempted local tobacco control efforts. ${ }^{103}$ The issue of preemption was particularly important as Arizona began to develop the anti-tobacco education programmes. Experience from other states, particularly California, indicated that a combination of a hard-hitting media campaign with local community-based activities designed to implement local tobacco control policies ${ }^{2} 19$ is effective in reducing tobacco consumption. If the tobacco industry succeeded in getting the legislature to preempt local tobacco control activities, it would have crippled the Proposition 200 anti-tobacco programme before it started. All bills containing preemption language related to local tobacco control were killed by the speaker of the house, Mark Killian (R, Mesa), an ally of the health advocates. ${ }^{57}$ 64-68

In 1996 and 1997, as in other states, ${ }^{63}{ }^{69}$ the tobacco industry persisted in attempting to pass preemption bills disguised as youth access bills or as a "strike all" amendment in bills unrelated to tobacco issues. ${ }^{10}$ Thanks to an educational campaign led by the Coalition for Tobacco Free Arizona, the press in Arizona opposed preemption and for three years the tobacco industry was unable to pass preemptive bills, despite strong political pressure. ${ }^{70-74}$ For example, in 1996, Killian killed a preemptive bill (SB 1384) approved in the Senate, despite a telephone call from Haley Barbour, then national chairman of the Republican Party, to lobby for SB 1384. (In the 1996 election cycle, when Barbour was chair of the Republican Party, Philip Morris and RJR Nabisco were the party's top contributors. ${ }^{75}$ No longer chair of the Republican Party, Barbour is now a lobbyist with the firm Barbour, Griffith \& Rogers, which represents the tobacco industry. ${ }^{76}$ )

\section{House Bill 2275: first step of implementation}

The enabling legislation for Arizona's Proposition 200 emerged as House Bill 2275, authored by Sue Gerard. Governor Symington signed it into law on 19 April 1995 and it became effective on 13 July $1995 .{ }^{77}$ HB 2275 designated the Arizona Department of Health Services (ADHS) as the agency responsible for the health education programme, with funds provided by the Health Education account. It allocated $\$ 10$ million for FY 96 (July 1995 to June 1996) and \$15 million for FY 97 (July 1996 to June 1997) for anti-tobacco education.

These caps on expenditures from the Health Education account were below the $\$ 27$ million and $\$ 29$ million in revenues the initiative raised for anti-tobacco education for FY 96 and FY 97 respectively. The legislature justified its decision as a conservative budget measure to allow ADHS to structure a programme without wasting taxpayers' funds during its startup period. ${ }^{58}$ The health advocates did not like the caps, but saw it as a compromise to get an appropriation bill passed. ${ }^{56}$ The appropriation caps in the first two fiscal years created an earmarked reserve fund in the Health Education account of approximately \$37 million, which could be used after 1 July 1997 (FY 1998), unless the legislature approved legislation stating otherwise. Therefore, according to HB 2275, once the programme was in place for two years, the caps would then be removed, providing the tobacco education programme the full $23 \%$ of the new tobacco tax revenues. The funds accrued in the "reserve" of the Health Education account in the two years of the caps could also be spent on tobacco education programmes.

In addition to appropriating money, HB 2275 created the 11 -member tobacco use prevention advisory committee (TUPAC). TUPAC's role is to "review and make recommendations" to ADHS on programmes "established and funded" with Proposition 200 funds, and to provide ADHS consultation regarding the biannual evaluation of the tobacco control programme. ${ }^{77}$ TUPAC is chaired by the ADHS director and has bipartisan representation from both houses of the Arizona legislature and six members of the 
community. Community representation is appointed by the leadership of the House, the Senate and the governor, each appointing two members. The community representatives serve at the pleasure of the appointing official. The CTFA provided a list of names of individuals whom it considered suitable to fill the role as community representatives on the committee. However, only Speaker Killian chose his two appointees from the list suggested by CTFA. The governor's and Senate's community appointees represented the retail industry and the alcohol industry (the distribution and sales of tobacco products are part of the retail industry). These representatives were viewed by the health community as antithetical to the goals of the health education programme.

HB 2275 also established that the organisations eligible to apply for tobacco tax funds were county health departments, community health centres, schools, universities, community colleges, and Native American tribes. The non-profit organisations involved in the campaign were excluded from applying for the health education funds. The restriction on eligible agencies was perceived by tobacco control advocates as a retaliation measure against Proposition 200 supporters, making good on the threats made early in the effort to pass the initiative. This action also appeared to preclude the organisations with the greatest experience in and commitment to tobacco control from participating in the programme. (Nonetheless, the law allowed these organisations to serve as subcontractors.)

In 1996 and 1997 Sue Gerard introduced several bills to lift the caps on expenditures. She succeeded in April 1997 with HB 2147. HB 2147 retroactively increased the funds allocated to the health education account to \$25 million for FY 1996-1997. It also included non-profits among agencies entitled to apply for Proposition 200 funds, increased expenditures of the Health Education account to $90 \%$ of the funds collected into that account. $^{78}$

\section{Attempts at diversion}

Governor Symington attempted, and failed, to divert money from the Health Education account several times. The 1997 attempt at tobacco tax funds diversion was made through a legislative budget proposal. Approximately $\$ 42$ million were to be diverted from the tobacco tax, $\$ 34.7$ million from the Health Education account and $\$ 7.6$ million from the research account to build a state hospital. An intense campaign waged by health advocates eliminated this proposal from the budget.

\section{ADHS: second step of implementing the programme}

The passage of HB 2275 in April 1995 was the first step in implementing Arizona's Tobacco Education and Prevention Program (AzTEPP). The second step was for ADHS to establish the programme structure. HB 2275 did not address issues concerning specifics of the implementation and development of the programme, such as the scope of the programme or what type of projects should be funded. These issues were left to the executive branch, acting through ADHS.

In May 1995, ADHS started to create the structure to manage AzTEPP. The programme was housed at the Center for Prevention and Health Promotion. The director of the new programme, Martha Clift, was chosen from the ranks of the Department of Health Services. Clift and the director of the center, Joel Meister, developed a strategic plan for the tobacco control programme with some input from the CTFA. The proposed strategic plan, Tobacco use prevention plan for the state of Arizona, has been the working document of the programme. However, it was kept in draft format. According to Meister ${ }^{79}$ this was done on purpose to avoid a watering down of the goals of the programme, such as limitation of the target population, if they had to seek formal approval, which would subject it to higher level political involvement. The draft strategic plan established the following purposes of the AzTEPP.

- To maintain and improve the health and quality of life of all Arizonans by reducing dependence on tobacco products through prevention and treatment and by reducing exposure to environmental tobacco smoke while protecting the rights of smokers, users of tobacco for ceremonial or religious purposes, and non-smokers alike.

- To provide information, education and training, and technical assistance to those communities and agencies willing to assume the responsibility for developing and conducting comprehensive communitybased, tobacco-use prevention programmes. ${ }^{80}$ The goals of AzTEPP are:

- All of Arizona's youth should be tobacco-free

- All Arizonans, and especially children, should be protected from environmental tobacco smoke

- All Arizonans who wish to quit using tobacco should have access to affordable, state-of-the-art cessation services. ${ }^{80}$

Each goal had specific objectives designed to provide measurable outcomes over a five-year period (1996 to 2001). It was not until July 1995 (after HB 2275 was signed into law) that Clift and Meister were able to start developing the operational guidelines for the programme.

There was no language in either Proposition 200 or HB 2275 restricting the target population of the tobacco control programme. However, the director of ADHS, Jack Dillenberg, through the request for proposals (RFPs) issued on 29 August 1995, limited the target population for AzTEPP to preadolescents, adolescents, and pregnant women and their partners. He justified his choice of targeting a specific group with the limited amount of funds, as the legislature had capped expenditures at $\$ 10$ million in the first year. $\mathrm{He}$ felt that this group (young people and pregnant women) would be the most susceptible to the messages conveyed initially by the programme. ${ }^{81}$ Revisions were not made until 
1998, when adult cessation was included as a goal for the programme.

\section{Efforts to weaken the programme}

As soon as the tobacco tax fund expenditure proposals were submitted to the Arizona secretary of state in August 1995, Dillenberg signed a $\$ 635000$ contract with the Phoenix Suns to use the National Basketball Association (NBA) team to educate children about the dangers of smoking. The scheme used players and the team's mascot in radio and television spots, and used the stadium billboards to display anti-tobacco messages. ADHS hoped to use the same kind of sports sponsorship that the tobacco industry uses, except in this case it would be to promote anti-tobacco messages. A similar contract, for $\$ 190000$, was awarded to the Arizona Cardinals football team. ADHS and its supporters in the public health community viewed these contracts as a way to launch the programme quickly in a highly visible manner and gain support and credibility while other aspects of the programme (such as the local projects and media campaign) were being developed. Dillenberg's rapid action, although designed to get the programme off the ground, created an opening for the tobacco industry to try to slow it down.

The tobacco industry challenged the legality of the Suns and Cardinals contracts through Steve Duffy, an attorney with the lobbying and law firm Ridge \& Isaacson, which represents the Tobacco Institute. In a 12-page memorandum dated 29 September 1995 to ADHS, ${ }^{82}$ Duffy alleged violations of the Arizona state government rulemaking process, including accusations of illegality in the contracts with the Phoenix Suns and Arizona Cardinals. Duffy also claimed that ADHS RFPs established programmes inconsistent with HB 2275, which he alleged limited the target population to children and pregnant women. The questions regarding the legality of the contracts were moot, according to ADHS legal counsel, as were questions related to violation of the rulemaking process. Further, HB 2275 did not limit the target population of the programme. Nevertheless, the media used these accusations to create controversy over how well ADHS was going to manage the funds. ${ }^{81}$

TUPAC members Michelle Ahlmer (who represents retailers) and Jack Braddock (who represents the alcoholic beverage industry) also took steps against the contracts with the two sports teams. They complained to the legislature and Dillenberg that they were not consulted before the sports teams' contracts were awarded and questioned their legality. In addition, Dillenberg's failure to communicate with TUPAC before signing the contract upset those legislators who were TUPAC members, who learned of the contracts through the newspapers. The matter was finally resolved with Dillenberg's assurance that the communications line between ADHS and TUPAC members remained open. Three months later, in January 1996, CTFA also responded to the "Duffy memo" in a letter to Dillenberg, arguing, as ADHS legal advisors had, that Duffy's claims were groundless. ${ }^{83}$ CTFA denounced Duffy's efforts as an attempt by the tobacco industry to intimidate ADHS and slow the process of implementing AzTEPP.

\section{The media campaign}

By December 1995 , a $\$ 5.5$ million media contract was awarded to Riester Corporation, an advertising firm in Phoenix, to conduct a campaign in which the "target population of the media programme during the first year of the contract shall be pre-adolescents and adolescents, pregnant women and their partners". ${ }^{84}$ ADHS did not want a campaign attacking the tobacco industry or stressing secondhand smoke or addiction, as had been done in California. Rather, it wanted to focus on health effects of tobacco use. ADHS was, by policy, avoiding the most effective anti-tobacco messages and concentrating on the less effective messages. ${ }^{85}$

Riester conducted research about knowledge, behaviour, and attitudes regarding tobacco with young people between the ages of eight and 17, and developed the tag line for the campaign: "TOBACCO. TUMOR CAUSING, TEETH STAINING, SMELLY, PUKING HABIT". A highprofile statewide media campaign started immediately, with several television advertisements, as well as promotional activities in malls and community events. The media campaign has been the most visible aspect of the programme, with research showing that the media spots reached $76 \%$ recall among the general public after the first six months. ${ }^{86-88} \mathrm{An}$ activity developed in conjunction with the media campaign was a 43-foot $(13.1 \mathrm{~m})$ mobile interactive exhibit, mounted inside a Hummer (a military all-terrain vehicle), called the "Ash Kicker". The exhibit mimicked a horror show demonstrating the dangers of tobacco use. It was used in tours across the state, in schools and public events, and it was redesigned for 1998, to keep children interested in visiting it. ${ }^{89}{ }^{90}$ In 1998 the media campaign was expanded to address smoking cessation.

\section{Local projects}

The RFP for the local projects ${ }^{91}$ stated that they were to "promote a comprehensive rather than a piecemeal approach to [tobacco use] prevention at the local level", in agreement with the goals and objectives of the statewide tobacco use prevention strategic plan. Part of the local project activities was to develop a coalition of agencies to work together in tobacco control, which would then develop the comprehensive plan for the locality, based on needs, priorities, and resources. Services to be provided included school and communitybased tobacco prevention and education, reduction of youth access to tobacco products, promotion of smoke-free environments, and cessation services. There were many instances in which county boards of supervisors at first did not support a local coalition's intention to respond to the RFP, based on fear of retaliation from the tobacco industry, such as threats of 
lawsuits and expensive referendum campaigns. ${ }^{18} 19$ Nevertheless, by 30 June 1996 all but two counties in the state had a local project.

The report of the first four months of funding (February through June 1996) ${ }^{88}$ showed that the activities that have been most developed were the creation of coalitions, tobacco use prevention, mainly in schools, some cessation, and little progress toward the promotion of smoke-free environments. In a TUPAC meeting in June 1997, Don Morris, one of the tobacco control activists, raised the issue of the lack of activities promoting smokefree environments. Morris distributed a memorandum urging all those involved with AzTEPP to encourage the local projects to move forward on all aspects of a comprehensive tobacco control programme. ${ }^{92}$ On that same memorandum, Morris questioned the de facto ADHS policy of not criticising the tobacco industry tactics to addict new smokers. In response to Morris' comments and memorandum, Dillenberg stated that it was his policy choice not to criticise the tobacco industry. At a TUPAC meeting in February 1998, Morris proposed a resolution to incentive local projects coordinators to move forward in the promotion of smoke-free environments. ${ }^{93}$ Morris criticised Department of Health AzTEPP staff of "intentionally, unintentionally or inadvertently" not including the creation of smoke-free environments in its priorities. As a result of Morris' pressure, TUPAC passed a resolution encouraging AzTEPP staff to support all goals of the programme, including the ones related to secondhand smoke, and to take part in "all pro-health activities, including supporting or defending pro-health initiatives in their various communities, consistent with their mission as ... public health-related workers, as long as support for any such specific initiatives or ordinances are not implemented with tax dollars nor during tax paid regular work hours" ${ }^{93}$ This resolution is in agreement with ADHS guidelines on lobbying, that allow staff of programmes funded by AzTEPP to be involved in policy debates as long as they state facts and not their personal opinions. ${ }^{94}$

ADHS, through the RFP, encouraged local projects to conduct public education and advocacy activities, but before the local projects funds were awarded there was already a rumour that the tobacco industry was waiting for the opportunity to accuse local coalitions of misusing state funds for lobbying. In several states, the tobacco industry has used public records Acts to harass local tobacco control activists and to misrepresent local coalitions activities, accusing them of using public funds for "illegal lobbying". ${ }^{27} 28595$ To eliminate this problem ADHS issued, in autumn 1997, policy guidelines clarifying what constitutes lobbying under Arizona law ${ }^{96}$ and legislature and ADHS regulations regarding the expenditure of the tobacco tax funds. ${ }^{94}$ What employees of projects funded by AzTEPP can do on their own time and money was the issue that Morris addressed by bringing forth the resolution approved by TUPAC, mentioned above. ${ }^{93}$

\section{Evaluation}

The evaluation of AzTEPP has proven problematic. Despite efforts by Clift, Meister, and others, no baseline survey was conducted before the launch of the media campaign and the other components of the health education programme. Thus, there are no data on prevalence of tobacco use, knowledge, beliefs, and attitudes related to tobacco among the target population and the population at large before the beginning of the programme. Meister and Clift asked a consortium of the three public universities in Arizona to collaborate in a comprehensive project for both baseline and ongoing evaluation. ${ }^{79}$ The plan developed by the consortium had a cost higher than the administration was willing to pay and it was not accepted. Further, top levels of the administration stated that they were interested only in prevalence of tobacco use. ${ }^{79}$

There were some data available through a Department of Justice juvenile survey and through Arizona's Behavioural Risk Factor Survey (BRFS), conducted in collaboration with the federal Centers for Disease Control and Prevention (CDC). ADHS did not consider the data adequate to answer programme evaluation questions - it wanted a specific survey about the knowledge, behaviour, and attitudes of Arizonans regarding tobacco use and tobacco control measures, such as clean indoor air and youth access policies. In addition, ADHS wanted a sample that would be demonstrative of the state's five regions, so local projects could use the results in planning their activities. ${ }^{97}$

A baseline survey was initiated in April 1996, by the epidemiology division of ADHS. It is a comprehensive adult and youth survey, with a large enough sample (6000 adults and 6000 young people aged $10-17$ years) to provide detailed information by region as well as to detect small changes longitudinally. The survey addresses issues related to behaviour, attitude, and knowledge regarding tobacco use and tobacco policies, including clean indoor air and smoke-free workplace policies. The youth survey took longer than originally predicted because some parents were reluctant to provide consent for their children to participate. ${ }^{97}$ The adult survey was completed in September 1996, and its results released in October $1997 .{ }^{98}$ The youth survey was finished in August 1997 and its results released in June 1998. ${ }^{99}$ These two surveys cannot accurately detect any impact of the tobacco control programme as they were conducted after the programme started.

Each recipient of Proposition 200 funds has an evaluation component in its proposal, and the local projects conduct standardised process and outcome evaluations. It is expected that by 1999 an ongoing system to evaluate the programme as a whole will be established.

A study commissioned by CTFA, and funded by ACS, released in October 1996, ${ }^{100}$ concluded that there was an $8.4 \%$ reduction in 
cigarette consumption, representing 16 million fewer packs sold in the state between December 1994 and December 1995, which was consistent with the drop that would be expected based on the price increase that accompanied the tax increase. As the study was finished before the AzTEPP was launched, no programme effect could be measured.

\section{Staffing problems}

The tobacco control programme has had staffing problems. While Martha Clift was originally assigned to direct the programme, it took over six months to ensure that a minimum number of fulltime, civil service status positions would be allocated to run the programme. While the bureaucratic problems (aggravated by a departmental freeze on outside hiring) creating positions were being dealt with, Clift used contract workers to assist in the early parts of programme development, such as writing the RFPs and setting the programme structure. She was finally given approximately 12 fulltime, civil service positions (half of what she requested), and was never able to fill all the vacancies in the positions created to run the programme, including the position of evaluation coordinator (which was not filled until April 1999). This lack of adequate staffing affected the programme and raised questions regarding ADHS's commitment to have an efficiently staffed and run programme.

Since December 1995, several of the original staff hired have left, including Clift, who was suddenly transferred to another unit within ADHS in August 1996. Despite a widespread view among the health groups that Clift was being removed because she was doing "too good a job" of fighting the tobacco industry, none of the health groups publicly protested this action. Clift was replaced with Rosalie Lopez, who served as interim director for a year, before taking the position on a fulltime permanent basis. Lopez had previously served as Symington's legislative liaison on health affairs. Meister left in January 1997 and in June 1997, Dillenberg resigned as director of ADHS. ${ }^{101}$

Since the inception of the programme, staff, including Clift and Meister, were aware of a not-so-subtle threat that their actions had to be approved by higher level administration at ADHS and by the governor's office, ${ }^{79}$ effectively leaving employees of the programme little freedom to apply their best professional judgement for the public health in the area of tobacco control.

\section{Discussion}

The passage of Proposition 200 was a landmark for Arizona tobacco control. As in other states, ${ }^{135-9} 2946$ it provided funds to develop tobacco control campaigns unprecedented in size in that state. The battles to secure that the funds are properly used and to fight preemption were expected. The fact that the coalition of public health and medical care organisations constitutes a united force made it impossible for the legislature to divert tobacco education money into medical care, as was the case in California ${ }^{6-8}$ and Massachusetts..$^{3-5} 946$

One of the major forces against the programme was Governor Symington and some members of the Senate. Indeed, two of Symington's staff were also partners in a public relations firm that represents the tobacco industry. ${ }^{58}$ However, health advocates did not use this fact to protect the programme, preferring to deal with the legislature and with ADHS. In September 1997 Governor Symington resigned his office due to a guilty verdict on an indictment related to the handling of state and personal finances. Secretary of State Jane Hull (R), took office, and has since demonstrated support for the tobacco control programme.

Limiting the programme to adolescents and pregnant women was problematic for several reasons. First, although primary prevention is an important element of any tobacco control programme, concentrating prevention efforts on children can reinforce the tobacco industry's message that tobacco use is "an adult custom". ${ }^{102}$ Second, it appears that young adults (18-24) are most responsive to anti-tobacco messages. ${ }^{103}$ Failing to target this group prevents the programme from having maximum effect. Moreover, these young adults are important role models for teenagers; reducing tobacco use among young adults may be the most effective way to reach teenagers. For this reason, in 1997 the California tobacco education and research oversight committee (the Californian equivalent of TUPAC) recommended in its master plan that the "youth" component of the media campaign be directed at $18-24$ year olds. ${ }^{104}$ Third, since the process of youth uptake takes several years with children only smoking a few cigarettes a month, even an effective primary prevention programme will take years to affect prevalence or consumption. Fourth, although it is important to reduce smoking among pregnant women, at any given time only a small portion of women (and no men) are pregnant. Thus, it is not an efficient use of mass media as the messages are only relevant to a small portion of the audience at any time. In 1998 the programme expanded its target population to include adult cessation among its activities and as another focus of the media campaign. ${ }^{78}$ This was partly in response to smoking constituents' complaints to legislators that they are paying the taxes but are not receiving services. ${ }^{58}$ If well designed, and combined with a comprehensive media campaign and coordinated with other local level efforts, the inclusion of adult cessation will contribute to improving Arizona's tobacco education and prevention programme.

The health groups failed to recruit allies at the Senate, where most "roadblock" amendments were inserted into legislation that would further complicate the implementation of the tobacco control programme and the appropriation of the tobacco tax money as determined in Proposition 200.

The refusal by ADHS to use strategies attacking the tobacco industry, highlighting the dangers of secondhand smoke and tobacco 
addiction, proven effective in other states, may hinder the long-term effectiveness of the programme. ${ }^{85}$ In addition, by restricting who could apply for grants, what messages could be delivered, and what activities would be the focus of the programme, Arizona did not profit from the expertise accumulated in the area of tobacco control. With the passage of HB 2147, it is expected that agencies with greater expertise in tobacco control will become more directly involved in implementing the goals of Arizona's tobacco control programme.

The lack of clarity about how the programme evaluation will proceed is troubling. The lack of evidence of the programme's progress could jeopardise the programme's future, making it more vulnerable to attacks by the legislature and the tobacco industry.

The cap on how much money could be used in the programme in the first two years led to a large reserve of funds. As in most states, Arizona is always looking for additional sources of funds, and unless the health groups pressure the government to free the funds on the reserve account to be used in a comprehensive tobacco control programme, the risk of losing the funds will persist. It is certain that the tobacco industry will continue its attack on the programme, continue to attempt to pass preemption bills, and suggest other ways in which the money could be spent. It is in the tobacco industry's best interests to keep the health education programme as limited as possible.

While Arizona's tobacco control advocates have essentially fought the tobacco industry to a draw at the state level, they have scored several victories at the local level. Several cities have strong clean indoor air or youth access ordinances despite aggressive attack by the tobacco industry. ${ }^{10}$ Arizona tobacco control advocates defeated a high profile attempt by the tobacco industry's National Smokers' Alliance to roll back a strong clean indoor air ordinance in Mesa. ${ }^{20-22}{ }^{105-110}$ With the AzTEPP local projects well under way, an increase in local level activity is expected. Arizona's tobacco control advocates appear well positioned and unified in their efforts to continue to press for local ordinances. The open question is whether they will build on this base and muster the resources necessary to realise fully the opportunities created by Proposition 200 at the state level.

\section{Conclusion}

Arizona's experience with Proposition 200, in addition to California's ${ }^{26-8}$ and Massachusetts' experience, ${ }^{3-59}$ provides public health advocates with further insight in their effort to control tobacco use in the United States. It is clear from the experience in these three states that the tobacco industry tactics to derail well-funded, statewide tobacco control programme rely on extensive lobbying of the legislature and the administration to first divert the funds into other programmes, and second to make sure that the existing programme is as weak as possible in the messages it relays to the public. At the same time the industry will con- tinue its efforts to pass preemptive legislation at the state level to stop community organising around tobacco control issues. To confront the industry, health advocates in states that passed initiatives to raise the tobacco tax and fund statewide tobacco control programmes must be united and politically involved. The coalition that was formed to pass the initiative must stay together, working toward the common goal of preserving the intent of the initiative and allocating the new revenues as approved by the voters. In all three states, the public has consistently supported the anti-tobacco programmes. Arizona is the first state to use this public support to prevent any diversion of funds away from tobacco control.

Another important lesson is that the battle is not restricted to the legislature. The tobacco industry will attempt to pressure high-level state administration officers, particularly the governor's office, in hindering the tobacco control programme efforts. This pressure may result in weaker messages for the media campaign, limitation of the scope and reach of the programme, and disruption of the work through unfounded accusations of mismanagement of funds. As in California and Massachusetts, Arizona health advocates have failed to counter some of these pressures.

Health advocates considering a tobacco-tax initiative to fund tobacco education programmes must be politically savvy, aggressive, and realise that approval of the initiative by the voters is only the first step in a long battle to implement an effective, statewide tobacco control programme. These initiatives turn health groups - who traditionally were marginal political players - into stewards of large sums of money for anti-tobacco programmes in the face of an aggressive opponent: the tobacco industry. They need to be willing to mobilise the grassroots support for tobacco control as leverage in their dealings with not only legislators, but also the governor and members of the executive branch charged with implementing the programme through competent, professional assistance from lobbyists. They need to devote the resources necessary to develop the expertise to monitor and influence the implementation of these tobacco control programmes. They must go beyond being willing to simply attack the tobacco industry, to confronting its political surrogates. To be effective stewards of these programmes, public health groups need to learn to act more quickly, decisively, and aggressively than they historically have.

This work was supported by National Cancer Institute Grant CA-61021, American Cancer Society Grant RD-394, and Brazilian Ministry of Sciences grant CNPq 204225/88-4

1 Traynor MP, Glantz SA. California's tobacco tax initiative: the development and passage of Proposition 99. F Health Polit Policy Law 1996;21:543-85.

2 Bal DG, Kizer KW, Felten PG, et al. Reducing tobacco consumption in California: development of a statewide anti-tobacco campaign. fAMA 1990;264:1570-4.

3 Begay ME, Glantz SA. Question 1 tobacco education outlays: from the 1994 fiscal year to the 1996 fiscal year. Amherst, from the 1994 fiscal year to the 1996 fiscal year. Amherst, Massachusetts: School of Public Health

Sciences, University of Massachusetts, 1995 .
4 Heiser PF, Begay ME. The campaign to raise the tobacco tax in Massachusetts [see comments]. Am $\mathcal{F}$ Public Health 1997;87:968-73. 
5 Koh HK. An analysis of the successful 1992 Massachusetts tobacco tax initiative. Tobacco Control 1996;5:220-5.

6 Balbach ED, Monardi FM, Fox BJ, et al. Holding government accountable: tobacco policy making in California, 1995-19 tute for Health Policy Studies, University of California San Francisco, 1997

7 Begay M, Traynor MP, Glantz SA. The twilight of Proposition 99: reauthorization of tobacco education programs and tobacco industry expenditures in 1993. San Francisco, California: Institute for Health Policy Studies, University of California San Francisco, 1994.

8 Monardi F, Balbach E, Aguinaga S, et al. Shifting allegiances: tobacco industry political expenditures in California, January 1995-March 1996. San Francisco, California: Institute for Health Policy Studies, University of California San Francisco, 1996.

9 Begay ME, Glantz SA. Question 1 tobacco education expenditures in Massachusetts, USA. Tobacco Control. 1997;6:213-8.

10 Aguinaga Bialous S, Glantz SA. Tobacco control in Arizona, 1973-1997. San Francisco, California: Institute for Health Policy Studies, University of California San Francisco, 1997.

11 Driscoll J, Stern M. Cynicism-causing, integrity-staining, smelly, puking tobacco-lobbying influence-buying habit Phoenix, Arizona: Arizona Citizen Action, 1997.

12 Monardi F, Glantz S. Tobacco industry campaign contributions are influencing legislative behavior in six states. $A m \mathcal{F}$ Public Health 1998;88:918-23.

13 Mayes K. Goodies often are in store for lawmakers who build 'cabinets'. Arizona Republic 1996 Jan 21:A12.

14 Sidener J, Mayes K. Lobbyists' influence spreads. Arizona Republic 1996 Jan 21:A1,A10,A11.

15 Sidener JM, K. Dollars and Bills. Arizona Republic 1996 Jan $21 \cdot \mathrm{A} 1, \mathrm{~A} 10, \mathrm{~A} 11$.

16 Sidener J, Mayes K. Watching suns from suites among hottest perks. Arizona Republic 1996 Jan 21:A12

17 Madonna M. Letter to Mark Killian re: SB 1384. Phoenix, Arizona: Coalition for Tobacco-Free Arizona, 1996

18 Samuels B, Glantz SA. The politics of local tobacco control. ҒAMA 1991;266:2110-17.

19 Traynor M, Begay M, Glantz SA. New tobacco industry strategy to prevent local tobacco control. FAMA 1993, 270:479-86.

20 Nowicki D. Tobacco lobby gives thousands to fight ban. Mesa (Arizona) Tribune 1996 Mar 15.

21 Nowicki D. National group adds funds to smoking ban backlash. Tribune Newspapers (Gilbert; Mesa; Tempe, Chandler; Arizona) 1996.

22 Sherwood R. Mesa backs restaurant smoking ban 2-to-1. Arizona Republic 1998 Mar 11

23 Election '94. Arizona Republic 1994 Nov 10:A28.

24 Arizona for a Healthy Future. Proposition 200: Tobacco Tax and Healthcare Act. Arizona, 1994

25 John Rivers C. Interview with Stella Aguinaga. Tempe, Arizona: Arizona Hospital and Healthcare Association, 1996 (unpublished).

26 Arizona Hospital Association. Gallup poll: health care reform top priority for Arizona residents. Tempe, Arizona: Arizona Hospital Association, 1994

27 Monardi F, O'Neill A, Glantz SA. Tobacco industry political activity and tobacco control policymaking in Colorado: 1983-1996. San Francisco, California: Institute for Health Policy Studies, University of California San Francisco, 1996.

28 Ross M. Tobacco tax campaigns: a case study of two states. Washington, DC: Advocacy Institute, 1996

29 Nicholl J. Tobacco tax campaign guide. Atlanta, Georgia: American Cancer Society, 1996.

30 Drago J. Interview with Stella Aguinaga. Tempe, Arizona: Arizona Hospital Association, 1995 (unpublished).

31 Erikson J. Hospitals opposing smoke tax: critics blame tobacco lobby. Arizona Daily Star 1994 May 31:A1, A9.

32 Nicholl J. Interview with Stella Aguinaga. Siegel \& Nicholl, Public Relation, Campaigns and Elections, 1995.

33 Blowing smoke (editorial). Arizona Daily Star $1994 \mathrm{Feb}$ 3:A 12.

34 Reagor C. Coalition aims to raise tax on tobacco to curb smoking. Business fournal $1994 \mathrm{Feb}$ 4:23.

35 Ameduri K. Goldwater joins smoking battle. Scottsdale (Arizona) Progress Tribune 1994 Feb 2:A3.

36 McClain C. 40-cent increase is urged. Tucson (Arizona) Citizen 1994 Feb 2:C1,C4.

37 Consider tax on nasty habit (editorial). Arizona Daily Sun $1994 \mathrm{Feb} 3$.

38 Cannella D. Cigarette foes open drive for 40c tax. Arizona Republic 1994 Feb 2:B1

39 Cheshire WP. Koop on the rampage, Sam's spending and the arrogance of office. Arizona Republic 1994 Oct 18

40 Fischer H. Koop visit shows support for cigarette tax measure. Tribune Newspapers (Gilbert; Mesa; Tempe; Chandler; Arizona) 1994 Oct 11.

41 Murphy M. Former surgeon general backs cigarette tax hike. Phoenix (Arizona) Gazette 1994 Oct 11:B1,B2.

42 Wilson S. Dr Koop uses deadly facts in long crusade against smoking. Arizona Republic 1994 Oct 12:A2.

43 Fischer H. Governor, GOP leaders fight drive to boost cigarette tax. Arizona Daily Star 1994 Mar 28:A1,A3.

44 Fischer H. Cigarette tax push targeted: GOP leans on initiative leaders. Tribune Newspapers (Gilbert; Mesa; Tempe; tive leaders. Tribune Newspapers (Gilbert;
Chandler, Arizona) 1994 Mar 27:A1,A6.

45 Cannella D. Cigarette-tax backers assail Symington. Arizona Republic 1994 May 4:B1.
46 Begay M, Traynor M, Glantz S. The tobacco industry in state politics and funding tobacco education in California. Am f Public Health 1993;83:1214-21.

47 Schwartz J. Unlikely allies opposed anti-smoking campaign. Washington Post 1998 Jan 20:A3.

48 Warren J, Morain D. Bid to dilute anti-smoking effort revealed. Los Angeles Times 1998 Jan 21:A3.

49 Bush C. Tobacco tax promoters publicize allegations of industry conspiracy. Arizona Capitol Times 1994 May $6: 1,2,3$.

50 Bush C. Senate president speaks out against tobacco tax initiative. Arizona Capitol Times 1994 Jan 7:2,84.

51 No More Taxes. Will hospital-sponsored Prop. 200's "education fund" face a debacle like California's? Phoenix, Arizona, 1994.

52 No More Taxes. California's anti-tobacco "health education" programs: how lack of accountability breeds "pure pork".

53 No More Taxes. How much can voters afford to throw at antismoking campaigns before it gets silly. Phoenix, Arizona, 1994.

54 Proposition 200: no (editorial). Arizona Republic 1994 Oct 21:B6.

55 Aguinaga S, Glantz SA. The use of public records acts to interfere with tobacco control. Tobacco Control 1995:4:222-230

56 Matt Madonna C. Interview with Stella Aguinaga. Phoenix, Arizona: American Cancer Society, 1995.

57 DeMenna K. Interview with Stella Aguinaga. Phoenix, Arizona: Nelson, Robb, DuVall \& DeMenna, Nelson Communications Group, 1995.

58 Gerard S. Interview with Stella Aguinaga Bialous. Phoenix, Arizona, 1997 (unpublished).

59 Fischer H. Senators vote to take over tobacco tax. Arizona Daily Star 1995 Mar 3:B1,B3.

60 Coppola C. Senate votes to alter tobacco tax. Tribune Newspapers (Gilbert; Mesa; Tempe; Chandler; Arizona) 1995 Mar 3:B4.

61 Aguinaga S, Macdonald HR, Traynor MP, et al. Undermining popular government: tobacco industry political expenditures in California, 1993-1994. San Francisco, California: Institute for Health Policy Studies, University of California San Francisco, 1995.

62 Arizona Hospital Association. Arizonans reassert support for tobacco tax. Tempe, Arizona: Arizona Hospital Association, 1995.

63 Siegel M, Carol J, Jordan J, et al. Preemption in tobacco control: review of an emerging public health problem. 7AMA 1997;278:858-63.

64 Fischer H. Back from the dead. Tempe (Arizona) Daily New Tribune 1995 Apr 10:A1,A7.

65 Fischer H. Lawmakers OK state liquor panel to regulate tobacco product sales. Arizona Daily Star 1995 Apr 6:A1.

66 Arizonans Concerned About Smoking. HB 2429: back from the dead. Scottsdale, Arizona: Arizonans Concerned About Smoking, 1995.

67 Uniform tobacco enforcement: not at any price (editorial). Arizona Republic 1995 Feb 21:B6.

68 Tobacco and tyranny (editorial). Arizona Daily Star 1995 Feb 27:10A.

69 Macdonald H, Aguinaga S, Glantz S. The defeat of Philip Morris Proposition 188 in California. Am $\mathcal{F}$ Public Health 1997;87:1989-96.

70 The tobacco regulation bill: in need of revision (editorial). Arizona Republic 1996 Mar 22:B4.

71 The tobacco regulation bill: hopelessly flawed (editorial). Arizona Republic 1996 Feb 14

72 Nilsson J. A phalanx of lobbyists win one for the tobacco industry. Arizona Republic 1996 Mar 23.

73 Nilsson J. In regulating tobacco sales, don't pre-empt municipalities. Arizona Republic 1996 Mar 16.

74 Spurn the tobacco hustlers (editorial). Arizona Daily Star 1996 Mar 3:D2.

75 O'Rourke L. Impact of 'soft money' brings call for reform. Sacramento (California) Bee 1997 May 20.

76 Wayne L. With GOP chief a lobbyist, donors are clients. New York Times 1997 Jun 8;s1:30.

77 Arizona revised statutes. Laws of 1995, chapter 275tobacco tax; Arizona Health Care Cost Containment System (House Bill 2275). Phoenix, Arizona, 1995

78 Arizona Department of Health Services. Tobacco education and prevention program : summary prepared for Tobacco Use Preven-
tion Advisory Committee. Phoenix, Arizona: ADHS, 1998.

79 Meister DJ. Interview with Stella Aguinaga. Phoenix, Arizona: Arizona Department of Health Services Center for Prevention and Health Promotion, 1996.

80 Arizona Department of Health Services Center for Prevention and Health Promotion. Proposed tobacco use prevention tion and Health Promotion. Proposed tobacco use prevention 81 Dillenberg J. Interview with Stella Aguinaga. 1996.

82 Duffy SJ. Memorandum to Jack Dillenberg, Director, Arizona Department of Health Services, 1995.

83 Coalition for Tobacco Free Arizona. Letter to Jack Dillenberg, Director, Arizona Department of Health Services, 1996.

84 Administrative and Financial Services Procurement Office. Solicitation No H6-001: media services. Phoenix, Arizona: Arizona Department of Health Services, 1995.

85 Goldman LK, Glantz SA. Evaluation of antismoking campaigns. FAMA 1998;279:772-7.

86 Arizona Department of Health Services. 'Smelly, puking' campaign reached millions in 1st year. Phoenix, Arizona: ADHS, 1997. 
87 Arizona Department of Health Services. Statewide youth tobacco-prevention campaign launched. Phoenix, Arizona: tobacco-prevention
ADHS, 1996.

88 Arizona Department of Health Services. Arizona tobacco education and prevention program legislative report fiscal year 1996. Phoenix, Arizona: Director's Office, ADHS, 1996. 89 Arizona Department of Health Services. 'Ash Kicker' newest 1996.

90 Arizona Department of Health Services. Revamped 'Ash Kicker' begins statewide tour. Phoenix, Arizona: ADHS, 1998.

91 Administrative and Financial Services Procurement Office. Solicitation No H6-004: local projects. Phoenix, Arizona: ADHS, 1995.

92 Morris D. Memo to TUPAC (Tobacco Use Prevention Advisory Committee) members. Phoenix, Arizona, 1997.

93 Morris D. TUPAC resolution to clarify subject concern expressed by local TEPP project staff; old business carried forward by ayreement of all TUPAC members at December meeting. Phoeagreement of all TUPAC

94 Arizona Department Of Health Services. Policy guidelines: lobbying activities. Phoenix, Arizona: ADHS, 1997.

95 Monardi F, Glantz S. Tobacco industry political activity and tobacco control policymaking in Washington: 1983-1996. San Francisco, California: Institute for Health Policy Studies, University of California San Francisco, 1996.

96 Arizona Secretary of State. Lobbying in Arizona. Phoenix, Arizona: Secretary of State, 1996.

97 Porter R. Interview with Stella Aguinaga. 1997.

98 Porter R. 1996 Arizona Adult Tobacco Survey Report. Phoenix, Arizona: Arizona Department of Health Services, 1997.
99 Porter R, Nowak J. 1997 Arizona Youth Tobacco Survey baseline report Phoenix, Arizona: Arizona Department of line report. Phoenix,
Health Services, 1998.

100 Hogan T. The impact of Proposition 200 on cigarette consumption in Arizona. Phoenix, Arizona: Coalition for Tobacco Free Arizona, 1996.

101 Snyder J. Health chief quits, hospital head out. Arizona Republic 1997 Jun 12.

102 Glantz S. Preventing tobacco use: the youth access trap. Am 7 Public Health 1996;86:156-8.

103 Pierce JP, Evans N, Farkas AJ, et al. Tobacco use in California. An evaluation of the Tobacco Control Program, 1989-93. La Jolla, California: University of California, San Diego, 1994.

104 Tobacco Education and Research Oversight Committee. Master plan. Sacramento, California: California Department of Health Services, 1997.

105 Anon. A health initiative for the city of Mesa. Mesa, Arizona: 1996.

106 Arizonans Concerned About Smoking. Smoke-free initiative to be on Mesa city ballot March 26, 1996. Scottsdale, Arizona: Arizonans Concerned About Smoking, 1995:1.

107 Arizonans Concerned About Smoking. Mesa voters pass landmark Proposition 200. Scottsdale, Arizona: Arizonans Concerned About Smoking, 1996:1.

108 Moeser C. Smoking-ban feud promises to heat up before Mesa election. Arizona Republic 1995 Nov 28.

109 National Smokers Alliance. Campaign finance report. Mesa, Arizona: NSA, 1996.

110 National Smokers Alliance. The Mesa saga continues. Mesa, Arizona: NSA, 1997:3.

\section{Tobacco Control <http://www.tobaccocontrol.com>}

Visitors to the world wide web can now access Tobacco Control either through the BMJ Publishing Group's home page <http://www.bmj.com $>$ or directly by using its individual URL < http://www.tobaccocontrol.com>. There they will find the following.

- Full text of all issues from Summer 1999 onward (open access to all until February 2000 and thereafter only to subscribers via password)

- Facility to send a rapid response to any article in the journal

- Contents lists of previous issues

- Members of the editorial board

- Subscribers' information

- Instructions for authors

- Details of reprint services.

A hotlink gives access to:

- BMJ Publishing Group home page

- British Medical Association web site

- Online books catalogue

- BMJ Publishing Group books

Suggestions from visitors about features they would like to see are welcomed. They can be sent to the editor at the email address on the inside front cover of this issue, or left via the opening page of the BMJ Publishing Group site or, alternatively, via the journal page, through "About this site". 